\title{
Fairness and Equity in Employment: A Case Study of a South African Municipality
}

\author{
Ntwanano Mathebula \\ Junior Lecturer \\ Department of Public Administration, University of Limpopo \\ Ntwanano.Mathebula@ul.ac.za
}

\section{Doi:10.5901/mjss.2014.v5n20p592}

\begin{abstract}
This paper investigated the practice of empowerment between male and female counterparts into top-management positions of the Capricorn District Municipality (CDM), South Africa from the years 2009 to 2012. In this study, the researcher used a quantitative document review approach with the case study research design. The population consisted of all municipal employees from all different employment levels. Data was collected using existing literature, Integrated Development Plans (IDPS), and Annual Reports from the CDM. The analysis was carried out from various employment levels with a view of portraying the tendency of marginalising female employees from occupying top-management positions of the municipality. The results of the study revealed that female employees at the CDM are denied the opportunity of serving at top hierarchies of management despite pieces of legislation introduced to curb this challenge. This paper recommends that gender equity policies be revisited in order to address marginalisation challenges, not only at a municipal level but also in all spheres of government.
\end{abstract}

Keywords: Municipality, Female employees, Top-management, Marginalisation

\section{Introduction}

The marginalisation of women is a feature prevalent in all realms of life. The workplace is no exception to this trend particularly in developing economies. In Saudi Arabia and other developing states in Africa for instance, there are still challenges in introducing women to the workforce despite their skill and experience required to hold managerial positions (Edigheji, 2006; AlMunajjed, 2010). As a developing country, South Africa is also confronted by backlogs of introducing female employees in top-management positions. After the coming into power of the democratic dispensation in 1994, the South African government has been extensively engaged in the verge of restoring dignity of women by introducing aggressive policies that aimed at treating both males and females equally (Alfers, 2006; Reitzes, 2009). However, according to Langston (1997); Burger \& Japhta (2010), this has not been an easy path, since employment and the promotion of women in municipalities and the public sector in general remains a thorn in the head. Despite some positive prospects displayed by municipalities with regard to equality in the past decade, females have not been equally represented in top-management positions in South African municipalities (Mutele \& Musehane, 2012). The marginalisation is prevalent despite the fact that women have proven beyond reasonable doubt to be leaders in their own right. For example, by heading families, raising children, founding and managing Community-Based Organisations, etc. Govender \& Vyas-Doorgapersad (2013: 106), argue that the involvement of women in South African municipalities can be used as a mechanism that ensures effectiveness and efficiency particularly in the provision of services. However, according to Payne (2009); Mehra \& Gupta (2006) it is delusional to realize that legislative frameworks have not been properly implemented in favour of women in top-management positions.

\section{Legislation and Policy Background}

The Constitution of the Republic of South Africa, 1996 is the supreme law of the country and any law or conduct inconsistent with it is invalid. The Constitution, 1996 upholds the principle of non-discrimination based on sexual orientation. It is on this basis that female employees cannot be denied a chance on merit to occupy top-management positions. Section 9 of the Constitution, 1996 is a point of departure for South African municipalities that ensures the appointment and promotion of females. There are other various pieces of legislation that followed up the provisions of the supreme law in an attempt to ensure that all forms of marginalisation and discrimination in the workplace are curbed. The Employment Equity Act, 1998 (55 of 198), is a principal piece of legislation for dealing with fairness and equity in employment matters in the workplace. The Act was promulgated to amongst others; uphold the provisions of Section 9 of the Constitution, 1996 in ensuring equity in the society in general and the workplace in particular. 
The Employment Equity Act, 1998 aims for equality by imposing the duty to:

- Eliminate unfair discrimination and;

- Take positive or affirmative measures to attract, develop and retain individuals from previously disadvantaged groups.

The provisions of the pieces of legislation mentioned above should be good enough in ensuring that the 'floodgates' of top-management positions in municipalities are opened to all gender groups. However, the sensitivity that men are more superior to women is negatively impacting on the objectives of the democratic dispensation of ensuring a fair and equitable work environment (Holmes \& Flood, 2013). Equality in the workplace can be addressed in different ways. It is clear that although there are legislative measures in place to ensure the equal representation of women in topmanagement positions, the problem that still persists is implementation. Due to the need for fairness and equity in the employment of females to the top-management positions, the Employment Equity Act, 1998 should be enforced by an external agency, particularly in municipalities where gender inequality seems rife.

\section{The Need for Fairness and Equity in South African Municipalities}

The prominence of ensuring fairness and equality in the employment processes within the realms of South African municipalities can't be miscalculated. According to Trzcinski \& Holst (2010), the percent of females in top-management positions when compared with male employees constitutes a major social indicator of the extent to which women have failed to achieve parity with men in the labour market. There are a vast number of rationales for the inclusion of females in top-management positions of municipalities. Fairness and equality in the employment of women in top-management positions can help in improving economic growth in a number of ways and enhancing the provision of services (Thevenon, 2009; Tsani, Parousson, Fragiadakis, Charalambidis, Capros, 2012; Olivietti, 2013). However, the benefits of employing women in leadership positions and the equality thereof are beyond the scope of this paper. A deduction can be made that the importance of fairness and equality in the employment of women in top-management positions in South African municipalities is equal and crucial in the effective provision of services to the communities.

\section{A Case Study of the Capricorn District Municipality}

CDM falls under the Limpopo Province, South Africa. The district is predominantly rural in nature but located in the capital of the province. The district forms a gateway to Botswana, Zimbabwe and Mozambique. In the boundaries within the jurisdiction of the municipality, both men and women in the district share a significant amount of poverty burdens but the burden is more and becomes heavier on women. Addressing the gender dimensions of poverty and creating gender responsive interventions enhances the likelihood of success of poverty reduction strategy efforts (Capricorn District Municipality: IDP 2012/13). The municipality does realize this backlog but it is equally surprising that the implementation of gender equality policies for the purposes of ensuring fairness and equity has not been attended to. CDM is not the only municipality in South Africa that is struggling to effectively deal with the implementation of gender equality policies. Sedibeng District Municipality is a classic example (Govender \& Vyas-Doorgapersad, 2013). It is against this background that this paper seeks to investigate the extent to which fairness and equity is applied and achieved in the employment and the promotion of females in the CDM.

\section{Presentation and Discussion of Findings}

The following section presents findings on the equity with regard to employment of females when compared to their male counterparts into top-management positions of the CDM. The information portrayed by the tables was extracted from the Annual Reports and the IDPs of the municipality between the years 2009 to 2012.

Figure 1: Female presentation as per employment category 2009 to 2012

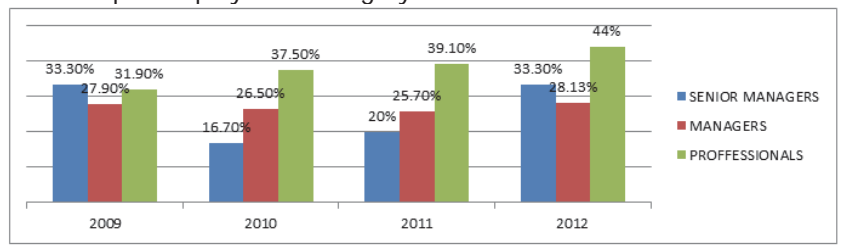

Source: Capricorn District Municipality Annual Report 2009, 2010, 2011, 2012. 
Figure 2: Male presentation as per employment category 2009 to 2012

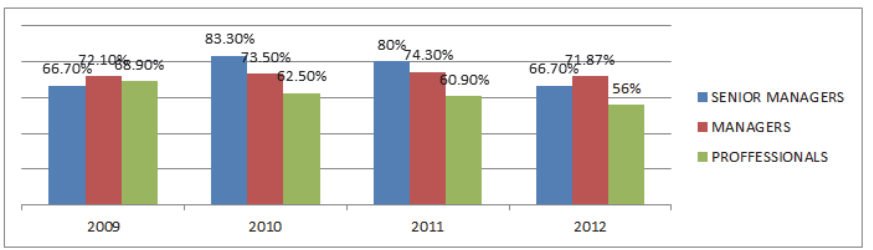

Source: Capricorn District Municipality Annual Report 2009, 2010, 2011, 2012.

The information as indicated by Figure 1 above depicts challenges in the employment categories of Senior Managers, Managers and Professionals. However for the purpose of this paper, senior managers and managers' categories are selected to describe the fairness and equity backlogs that exist within the CDM. Figure 2 above exposes the fact that more males occupied than females, senior management and management positions between 2009 to 2012. The average of males occupying senior management positions from 2009 to 2012 in the CDM is $74.3 \%$ as compared to the $25.7 \%$ for females. $26.9 \%$ of females occupied management positions from 2009 to 2012 opposed to a staggering $73.1 \%$ of males in the similar period.

The information provided by Figure 1 above reconnoitres the underrepresentation of females in top-management positions of the municipality. Despite the fact that there are mechanisms in place in support of gender equality, the representation of women in top-management positions have instead been declining since 2009 to 2012.

\subsection{Senior Managers}

The representation of women in senior management level as compared to their male counterparts from the year 2009 to 2012 as provided by Figure 1 is 33.3\%, 16.7\%, 20\% and 33.3\% respectively. The CDM is inconsistent when it comes to empowering women in senior management positions. There has been a steady decline from $33.3 \%$ in 2009 to an appalling $16.7 \%$ in 2010 and $20 \%$ in 2011. The result shown here suggests discrepancies in the implementation of gender equality in the CDM. However, it should be acknowledged that there has been a steady improvement in 2012, where female representation in senior management positions rose to $33.8 \%$. Based on the above analysis, it can be concluded that, although there has been an unstable and discouraging female representation in senior management positions, the year 2012 gave some positive forecasts.

\subsection{Managers}

Figure 1 above indicates that since 2009 to 2012, the representation of females in management positions as compared with males is $27.9 \%, 26.5 \%, 25.7 \%$ and $28.13 \%$ respectively does not represent fairness in employment. The statistics stamps the authority, and eludes that females are underrepresented in management positions as is also the case at senior management level. It therefore, becomes clear that, males continue to boast top-management positions in the CDM and tis may extend to other South African municipalities. From 2009 to 2011, the municipality has witnessed a steady decline in the representation of females in management positions. In 2009 the representation of females was $27.9 \%$ while it fell to $26.5 \%$ in 2010 and $25.7 \%$ in 2011 respectively. Although the Annual Reports of the municipality do not provide 'push-factors' for these declines, it is presumed that the municipality favours male promotions into management positions than their female counter parts. However, it should be acknowledged that the municipality witnessed a growth in female representation in management position in 2012 where $28.13 \%$ of females occupied management positions.

The statistics depicted in Figure 1 above; indicate that women are underrepresented in senior management and management levels. The information above in Figure 1 and 2 is compiled through the information obtained for the Annual Reports and IDPs of the CDM. The IDP (2012/13) of the municipality acknowledges the problem of women underrepresentation in top-management positions and states that: "addressing the gender dimensions of poverty and creating gender responsive interventions enhances the likelihood of success of poverty reduction strategy efforts". However the municipality does not convert its ambitions into practice as it is palpable that women are not being given preference for top-management employment. 


\section{Conclusion}

Achieving fairness and equity in the employment of females in top-management positions of municipalities and the public sector in general remains a stumbling-block in South Africa. Such discrepancies and tendencies manifest despite the fact that the country has transcended into a democratic dispensation in the past twenty years. This paper therefore concludes that there are strides that need to be made in the advancement of female employees and their rights into the democracy. The CDM and other South African municipalities are required by various pieces of legislation in ensuring that there is fairness and equity in the workplace. This however does not manifest into practicality due to policy implementation. South African municipalities are also required to implement and promote gender equality policies so as to ensure that the capacity and skill of women. However it should be acknowledged that the implementation of gender equality policies is succeeding in other aspects of municipalities. This includes the fact that more women are employed in municipalities as compared to such as the fifteen and twenty years back. This paper recommends that the implementation of equity policies should be done by an independent body that would also compels municipalities and other organs of state to on the basis of merit consider women for top-management positions. Furthermore training and the development of women for the purposes of capacity building is equally crucial.

\section{References}

Alfers, L.C. (2006). Stirring the hones nest: Women's citizenship and childcare in post-apartheid South Africa.

AlMunajjed, M. (2010). Women's Employment in Saudi Arabia a Major Challenge. http://www.booz.com/media/file/ Womens_Employment_in_Saudi_Arabia.pdf. (Accessed 30 May 2013).

Burger, R. \& Jafta, R. (2010). Affirmative action in South Africa: an empirical assessment of the impact on labour market outcomes. CRISE Working Paper No. 76. Centre for Research on Inequality, Human Security and Ethnicity.

Capricorn District Municipality. (2012). Integrated Development Plan, 2012/2013.

Edigheji, O. (2006). Affirmative Action and State Capacity in a Democratic South Africa. Policy: Issues \& Actors, 20 (4). This paper was presented at the 29-30 June 2006 CPS international seminar on IBSA Within a Changing Global Order: Regional and Human Security Dimensions' held in Johannesburg, South Africa.

Govender, S.D. \& Vyas-Doorgapersad, S. (2013). The Implementation of Gender Equality Policies in Achieving Millennium Development Goal Three in the Sedibeng District Municipality. Journal of Public Administration. 48 (1): 105-117.

Holmes, S. \& Flood, M. (2013). Genders at Work: Exploring the role of workplace equality in preventing men's violence against women. http://www.whiteribbon.org.au/uploads/media/Research_series/WRIB-470_Genders_At_Work_Paper_v03.pdf. Accessed 18 June 2014.

Langston, L.R. (1997). Affirmative action, a look at South Africa and the United States: a question of pigmentation or levelling the playing field? American University International Law Review, 13 (2): 322-377.

Mehra, R. \& Gupta, G.R. (2006). Gender mainstreaming: making it happen. http://www.icrw.org/files/publications/Gender-MainstreamingMaking-It-Happen.pdf. (Accessed 07 June 2013).

Mutele, T.C. \& Musehane, N.M. (2012).The Prospects and Challenges of Women in Leadership Positions. A Case Study of Thulamela Municipality. International Journal of Humanities and Social Science. 2 (23): 226-229.

Olivietti, C. (2013). The female labour force and long-run development: the American experience in comparative perspective. Paper presented in Human Capital in History: the American Record conference in Cambridge, MA, 2012.

Payne, S. (2009). How can gender equity be addressed through health systems? Policy brief 12. http://www.euro.who.int/_data lassets/pdf_file/0006/64941/E92846.pdf. Accessed 07 June 2013).

Reitzes, M. (2009). The impact of democracy on development: the case of South Africa. Research Report 120. http://www.cps.org.za/cps\%20pdf/RR120.pdf. (Accessed 07 June 2013).

Republic of South Africa. (1996). Constitution of the Republic of South Africa, 1996. Pretoria: Government printers.

Republic of South Africa. (1998). Employment Equity Act, 1998 (55 of 1998). Pretoria: Government printers.

Thevenon, O. (2009). Increased women's labour force participation in Europe: progress in the work-life balance or polarization of behaviours? Population-E, 64 (2): 235-272.

Trzcinski, E. \& Holst, E. (2010). Gender Differences in Subjective Well-Being in and out of United States Agency International Development. 2012. Gender equality and female empowerment policy.

Tsani, S., Parousson, L., Fragiadakis, C., Charalambidis, I. \& Capros, P. (2012). Female labour force participation and economic development in Southern Mediterranean countries: what scenariors for 2030? MEDPRO Technical Report No. 19/ December 2012. 